\title{
Kondisi Politik di Kesultanan Bima (1915-1950)
}

\author{
Sumiyati \\ sumimaci068@gmail.com \\ STKIP Yapis Dompu NTB
}

\begin{abstract}
Bima Sultanate is one of the kingdoms located on Sumbawa Island, NTB. At the end of the Dutch colonial period the Sultanate of Bima recognized Indonesian independence and recognized its sovereign territory as part of Indonesian territory. Politics in the Sultanate of Bima until 1915 was under the supervision of the Dutch East Indies government, although this situation was not taken for granted, much resistance was carried out even though it was successfully suppressed by the Dutch army. The research method used is the historical method and literature study by prioritizing archival sources and previous works relevant to the theme of writing. The results of this study explain that the Sultanate of Bima became one of the pioneers in the struggle for independence in Eastern Indonesia, especially representing the island of Sumbawa which has three kingdoms that are still in power. Besides that, in the period from 1915 to 1950 the Sultanate of Bima sought a new identity in the new political identity, the political system of the sultanate's monarchy had to adjust to the new order after the proclamation of independence
\end{abstract}

Keywords; the Bima sultanate, Bima's early independence, politics in the Bima sultanate

\begin{abstract}
Abstrak
Kesultanan Bima adalah salah satu kerajaan yang terletak di Pulau Sumbawa, NTB. Pada akhir masa kolonial Belanda, Kesultanan Bima mengakui kemerdekaan Indonesia dan mengakui wilayah kedaulatannya sebagai bagian dari wilayah Indonesia. Politik di Kesultanan Bima sampai 1915 berada di bawah pengawasan pemerintah Hindia Belanda, meskipun berhasil ditekan oleh tentara Belanda. Metode penelitian yang digunakan adalah metode historis dan studi literature dengan memprioritaskan sumber arsip dan karya sebelumnya yang relevan dengan tema penulisan.hasil penelitian ini menjelaskan bahwa Kesultanan Bima menjadi salah satu pelopor dalam perjuangan kemerdekaan di Indonesia Timur, terutama mewakili Pulau Sumbawa yang memiliki tiga kerajaan yang masih berkuasa. Selain itu, pada periode 1915 hingga 1950 Kesultanan Bima mencari identitas baru dalam identitas politik baru, system politik monarki kesultanan harus menyesuaikan diri dengan orde baru setelah proklamasi kemerdekaan.
\end{abstract}

Kata Kunci; kesultanan Bima, Bima awal kemerdekaan, politik di kesultanan Bima 
Sumiyati

Kondisi Politik di Kesultanan Bima (1915-1950)

\section{Pendahuluan}

Dalam perjalanan Sejarah kabupaten Bima dulunya merupakan wilayah kesultanan dengan catatan sejarah yang panjang. Kekuasaan dan pengaruh Bima meliputi Pulau Sumbawa bagian timur hingga dataran pulau Flores. Pada masa Kolonialisasi kesultanan Bima tidak luput dari penjajahan Kolonial Belanda, sampai pada Belanda menyerah tanpa syarat kepada Jepang. Setelah berkuasa, Jepang memanfaatkan sumber daya alam serta sumber daya manusia yang berada di Indonesia khususnya Bima, tentara Jepang mempekerjakan rakyat Bima tampa memperhatikan kondisi fisik, umur, suku, agama serta jenis kelamin. Kedatangan bangsa Jepang di Bima adalah merupakan rangkaian politik yang didukung oleh kekuatan militer yang sangat berkembang yang telah berhasil membangun pertahanan sehingga dengan mudah dapat menaklukkan daerah-daerah yang diinginkannya. Tokoh yang memegang peran utama dalam perkembangan sejarah Bima pada awal abad ke-20 adalah putra Sultan Ibrahim dengan permaisurinya Siti Fatimah Binti Lalu Yusuf Ruma Sakuru yaitu Sultan Muhammad Salahuddin (Ismail, 2004a). Muhammad Salahuddin lahir pada tanggal 14 Juli 1888. Sebagai putra Sultan Bima, Sultan Salahuddin belajar sistim dan tata politik kesultanan, dengan bekal ilmu yang telah dimilikinya tersebut Sultan Salahuddin memiliki kemampuan yang cukup sebagai calon Sultan. Pada tahun 1915, tonggak pimpinan Kerajaan Bima mulai dipegang oleh Muhammad Salahuddin sebagai Sultan yang sebelumnya menjabat sebagai Tureli Donggo, beliau menggantikan kedudukan ayahandanya yang mangkat pada tanggal 16 Desember 1915.

Sebelum Sultan Salahuddin menjadi seorang raja kondisi perpolitikan yang ada di Bima berada dalam pengawasan dan kekuasaan pemerintah Hindia Belanda sebagai penguasa dengan menerapkan sisitim sentralisasi. Kesultanan Bima sebagai salah satu wilayah Hindia Belanda yang diikat dalam berbagai perjanjian dan kontark politik. Perjanjian 1908 merupakan salah satu pernyataan yang menyatakan bahwa Kerajaan Bima telah menjadi bagian dari Hindia Belanda, dengan demikian, Belanda memiliki hak dalam mengatur urusan rumah tangga Kerajaan Bima seperti yang diuraikan dalam surat yang di tujukan pada Gubernur Swart antara lain:

Supaya pemerintahan yang elok, Kerajaan Bima dibagi dalam 5 pemerintahan (distrik).

1. Pemerintahan Distrik RasanaE diperintah oleh Jeneli RasanaE yaitu Sultan Sendiri.

2. Pemerintahan Distrik Donggo diperintah oleh Jeneli Donggo yaitu Sultan Muda.

3. Pemerintahan Distrik Sape diperintah oleh Jeneli Sape yaitu Raja Bicara.

4. Pemerintahan Distrik Belo diperintah oleh Jeneli Belo yaitu Raja Sakuru.

5. Pemerintahan Distrik Bolo diperintah oleh Jeneli Bolo yaitu Rato Parado (Tajib, 1995). 
DIAKRONIKA 20 (1) 2020

ISSN: 1411-1764 (Print) | 2620-9446 (Online)

Ditetapkan lebih lanjut dalam surat tersebut bahwa: "Maka dari sebab bagian pemerintah (distrik) ini kemudian cuma 4 mantri yaitu Sultan Muda, Raja Bicara, Raja Sakuru, dan Rato Parado dan 4 mantri ini ialah hadat tanah Bima dan mentri Kerajaan Bima dan Sultan. Lain-lain mantra telah dilepas oleh kita dan tidak boleh mencampuri urusan pemerintahan. Jadi kita larang sekali-sekali campur pemerintahan dan siapa yang melanggar nanti kita buang dari Tanah Bima. Sejak saat itu secara resmi Kerajaan Bima menjadi bagian dari wilayah pemerintahan Kolonial Belanda yang berpusat di Makassar kemudian diperbaharui pada tahun 1909 yang menyatakan kerajaan yang berada di Pulau Sumbawa masuk dalam administrasi Keresidenan Timur (ANRI, 1929). Dengan adanya penetapan Kesultanan Bima sebagai bagian dari pemerintahan Hindia Belanda mengakibatkan semua urusan kerajaan harus diketahui dan mendapat ijin dari pemerintah Kolonial Belanda, dan hal ini telah menghilangkan independensi kesultanan Bima sebagai sebuah kerajaan yang mandiri. Keterkungkungan kesultanan Bima dalam aturan-aturan Kolonial Belanda, walaupun dikatakan sudah berlangsung lama, tetap memberikan ruang gerak bagi penguasa lokal dalam menentukan kebijakan dalam pemerintahannya.

Pada masa sebelumnya yaitu masa kepemimpinan ayah dari Sultan Muhammad Salahuddin, bentuk pemerintahan terdiri dari "Sara-Sara" yang dipimpin oleh Ruma Bicara (Wakil Sultan), "Sara Tua" (Sara Tua disebut juga sebagai suatu dewan perwakilan yang beranggotakan para pejabat Hadat dalam Istana dibawah pimpinan Bumi Luma RasanaE dan Bumi Luma Bolo masing-masing) yang dipimpin oleh Sultan, dan "Sara Hukum" yang dipimpin oleh Qadi, namun kedudukan dan posisi serta fungsi tersebut kemudian diganti dan dirombak oleh pemerintah Kolonial Belanda berdasarkan isi traktat panjang yang dipaksakan. Sejak itu Sara Hukum tidak dianggap lagi sebagai bagian dari Majelis Hadat yang berperanan dalam pemerintah Kerajaan Bima. Kolonial Belanda sengaja menghapus Sara Hukum, karena selama Sara Hukum masih berfungsi sebagai Lembaga Majelis Hadat, selama itu pula pemerintahan Kerajaan Bima masih berdasarkan Islam dan hal tersebut dianggap membahayakan Belanda. Sejak itu struktur pemerintahan Kerajaan Bima hanya terdiri dari Sara-Sara dan Sara Tua. Secara otomatis Islam tidak lagi berpengaruh secara langsung dalam pemerintahan, dan pada masa pemerintahan Sultan Muhammad Salahuddin masih terdiri dari Sara-Sara dan Sara Tua.

Penguasaan Belanda terhadap rakyat menjadikan pemerintah kolonial berhak memungut pajak, tanpa mengindahkan hukum adat Binti (Ismail, 2004a). Kerajaan telah kehilangan kedaulatannya sehingga tidak lagi dapat leluasa melindungi rakyatnya. Hal ini oleh rakyat Bima dipandang sebagai pelanggaran dan penjajahan (karangga wari). Sara Hukum tidak diterapkan lagi dalam bidang pemerintahan, sesuai dengan isi 


\section{Sumiyati}

Kondisi Politik di Kesultanan Bima (1915-1950)

kontrak politik panjang (Lange Kontrak) yang sebelumnya ditanda tangani oleh Sultan Ibrahim pada tahun 1906, bagi para pejabat yang menduduki posisi tersebut dimanfaatkan oleh Sultan bersama Ruma Bicara untuk dijadikan wadah yang mengurus pendidikan agama. Masa pemerintahan Sultan Muhammad Salahuddin ada beberapa kali perubahan dalam batas wilayah hal tersebut dipengaruhi oleh hilangnya kekuasaan Bima di wilayah timur yaitu pulau Flores. Pada tahun 1928 (ANRI, 1929), Manggarai melepaskan diri dari wilayah Kerajaan Bima namun Bima menerima bekas Kerajaan Sanggar dan kerajaan Dompu pada tahun 1929 (ANRI, 1929) sebagai salah satu wilayah kerajaan Bima. Hal ini merupakan bagian dari tekanan yang dilakukan oleh Belanda terhadap kesultanan Bima pada saat itu. Pada tahun 1944, Bima dipecah menjadi dua daerah Swapraja yaitu Swapraja Bima dan Swapraja Dompu. Perkembangan terakhir menjadi kabupaten Bima dan kabupaten Dompu (Tajib, 1995).

Perkembangan wilayah kekuasaan Kerajaan Bima pada masa pemerintahan Sultan Muhammad Salahuddin, terutama dalam bidang politik dan pemerintahan mengalami pasang surut, dan itu dipengaruhi faktor dari dalam dan luar, hal ini sangat menentukan sejarah perkembangan Kerajaan Bima dalam bidang politik dan pemerintahan. Sultan Salahuddin selama menduduki kursi kesultanan Bima tetap melaksanakan tugasnya sebagai pemimpin bagi rakyatnya, banyak kebijakan yang telah diterapkanya dalam lingkungan istana sebagai bentuk dari penegasan diri atas rakyat dan tanah yang dimilikinya sebgai penguasa, walaupun pada kenyataanya pemerintah colonial Belanda selalu berusaha mengendalikannya dalam segala hal.

\section{Metode Penelitian}

Pada penulisan ini menggunakan metodologi sejarah dengan tahapan mulai dari Heurustik, kritik, interprestasi kemudian historiografi. Dalam langkah pertama, yang disebut dengan heuristic yaitu mencari dan mengumpulkan sejumlah data dan informasi dengan jalan membaca buku-buku, skripsi, tesis, dan disertasi yang mempunyai hubungan dengan masalah yang diteliti atau yang akan dibahas dalam skripsi ini. Langkah ini diharapkan agar bisa tercapainya atau diperolehnya data dan informasi tentang masalah yang akan diteliti. Dalam karya ini, menggunakan sumbersumber Sekunder (arsip, dokumen terkait, buku-buku hasil karya terdahulu, skripsi, tesis). Selain itu sumber yang diperoleh selain sumber tertulis ada juga sumber lisan yang merupakan hasil wawancara dengan beberapa saksi sejarah dan keturunannya. Setelah data-data terkumpul, kemudian langkah selanjutnya, pada adalah melakukan pengujian terhadap sumber-sumber tersebut atau yang dikenal dengan kritik eksternal dan kritik internal untuk mengetahui apakah suatu dokumen atau data itu otentik (keaslian sumber) atau tidak. Sementara, penggunaan kritik internal untuk mengetahui apakah data tersebut akurat dan relevan dengan kejadian yang sesungguhnya. Dengan 
demikian akan mudah diketahui mana sebenarnya data yang terlalu banyak bersifat subyektif dan mana pula sumber yang mendekati kebenaran.

Setelah mendapatkan fakta yang diakui kredibilitasnya maka langkah selanjutnya ialah merangkai fakta-fakta tersebut menjadi karya sejarah, pada tahap ini dilakukan interpretasi atau tahap penafsiran. Data yang diperoleh dari berbagai sumber kemudian dihubungkan satu-sama lain untuk mendapatkan suatu pemaknaan yang utuh mengenai masalah yang menjadi fokus kajian. Kemudian dari sumber-sumber yang dikumpulkan yang berkaitan erat dengan tujuan penelitian, dan kemudian masuk pada tahapan bentuk realisasi dari sumber tersebut dengan melakukan penulisan sejarah (historiografi) secara sistematik.

\section{Pembahasan}

\section{Peran Sultan Salahuddin sebagai pemimpin Politik}

Usaha Sultan Muhammad Salahuddin dalam mempersiapkan kemerdekaan melalui pendidikan ternyata bisa dilaksanakan dengan tidak mendapat halangan yang berarti dari pihak Kolonial Belanda. Dalam mendirikan sekolah di wilayah Bima, Sultan mendirikan Sekolah Islam di kota Raba dan di Kampo Suntu Bima. Selain itu juga Sultan mendirikan mesjid-mesjid di tiap-tiap desa. Sementara di dalam Kerajaan Bima Sultan Muhammad Salahuddin mendirikan suatu badan peradilan agama yang disebut Mahkamatun Syari'ah, atau Badan Hukum Syara, untuk memutuskan dan mengatur hal-hal yang berhubungan dengan hukum Islam dan hukum adat (Tajib, 1995). Menjalankan roda pemerintahan dalam situasi yang tidak menentu bukan berarti membuat Sultan Salahuddin menutup diri dari perkembangan nasional, pada masanya Indonesia berada dalam masa zaman yang bergerak kearah kebebasan dari kolonialisme. Sultan Salahuddin selain sebagai seorang Sultan beliau juga adalah seorang Nasionalis yang cukup aktif dalam ikut mempropagandakan pergerakan Nasional. Persatuan dan kemerdekaan bagi seluruh wilayah Indonesia disadari sepenuhnya sehingga Sultan tidak menutup diri dari perkembangan nasional hal ini bisa dilihat dengan banyaknya organisasi-organisasi Nasional yang berkembang di Bima.

Pada masa Sultan Muhammad Salahuddin, Bima membangun tonggak sejarah dalam hal perlawanan terhadap Hindia Belanda, perlawanan yang dilakukan selalu dengan cara melakukan aksi-aksi perebutan kekuasaan yang bersifat frontal. Hal tentu menyebabkan suhu politik di Kesultanan Bima memanas dan tidak jarang menjadi kemelut politik. Perlawanan tetap dilancaran dengan berbagai bentuk hingga akhirnya melahirkan perkumpulan-perkumpulan, organisasi pergerakan dan bahkan partai 
Sumiyati

Kondisi Politik di Kesultanan Bima (1915-1950)

untuk melawan Kolonial Belanda. Beberapa organisasi politik yang terbentuk pada masa Sultan Slahudin antara lain sebagai berikut:

\section{a. Serikat Islam.}

Pada tahun 1920 berdiri partai politik dengan nama Sarekat Islam (SI). Kehadiranya di Bima pada awalnya di perkenalkan oleh seorang ulama yang bernama Haji M. Tahir dari Banjarmasin. Sarekat Islam menempatkan dirinya sebagai perkumpulan pelopor dalam pergerakan di Bima. Sarekat Islam membawa aspirasi perjuangan untuk menghapuskan kerja paksa atau kerja rodi dan menolak pajak (belasting) yang memberatkan rakyat. Pergerakan Nasional yang berkembang di pulau Jawa, menyebar masuk ke wilayah Nusa Tenggara. Pada tahun 1920, Sultan Muhammad Salahuddin menyambut baik berdirinya organisasi pergerakan pertama yaitu Serikat Islam yang dibentuk di wilayah Bima dengan tujuan menentang para Kolonial Belanda. Sultan Muhammad Salahuddin memberikan restu berdirinya Serekat Islam di Bima dengan mengijikan "oknum" pejabat Kerajaan menjadi anggota dan menduduki jabatan pengurus. Dalam waktu yang relatif singkat Sarekat Islam berkembang sampai di desa-desa. Keberhasilan itu dapat dicapai karena salah seorang pengurusnya adalah seorang ulama besar dan berwibawa di Bima yang bernama Syekh Muhammad Mansyur. Dikalangan rakyat umum partai Sarekat Islam disebut partai Ruma Sahe (Tajib, 1995).

Perkembangannya Serekat Islam hanya berlangsung selama tiga tahun dalam pengurusannya, Serikat Islam yang sedang dalam masa pertumbuhan oleh Kolonial Belanda pada tahun 1923 dipaksa untuk dibubarkan. Namun bagi para bekas anggota Sarekat Islam tidak membuat mereka berputus asa, mereka sama sekali tidak kehilangan momentum untuk melanjutkan perjuangan Sarekat Islam. Semangat tersebut melahirkan ide dalam perkumpulan mereka Mereka untuk mengubah taktik perlawanan. Untuk melanjutkan perjuangan tersebut mereka mendirikan perkumpulan perdagangan dengan nama Setia Utama. Kountrolir Bima belum juga puas dengan membubarkan Sarekat Islam, dengan demikian usaha Setia Utama yang mulai menunjukan keberhasilan berusaha dihalangi pula oleh Belanda. Hal tersebut dilakukan dengan cara menginstruksikan kepada pedagang bangsa Asing yang bermukim di Bima dianjurkan untuk memboikot kegiatan dagang Setia Utama. Demikian berat tekanan yang dilakukan pemerintah Kolonial Belanda. Pemboikotan oleh saingan dagang yakni pedagang bangsa asing tidak mengenal ampun, tekanan yang upaya menghalanghalangi membuat kegiatan dagang Setia Utama menjadi porak poranda dan tak berdaya lagi. 
DIAKRONIKA 20 (1) 2020

ISSN: 1411-1764 (Print) | 2620-9446 (Online)

\section{b. Pembukaan Sekolah Islam.}

Pada tahun 1921, pemerintah Hindia Belanda membuka Holland Inlandsche School (HIS) untuk anak-anak golongan elite. Masyarakat Bima yang terkenal taat pada agama, menaruh kecurigaan pada materi pendidikan yang merupakan produk dari Belanda yang dianggap sebagai orang kafir (dou kafi) (Tajib, 1995). Hal ini menimbulkan kesulitan bagi Sultan yang berniat memajukan pendidikan rakyatnya. Selain itu anakanak bumiputra karena kemiskinan tidak dapat menjadi siswa sekolah tersebut. Sehingga masalah pendidikan bagi anak-anak Bumiputera perlu dicari jalan keluarnya. Di kalangan pejabat kerajaan, pemuka masyarakat, dan agama membuka sekolah agama untuk anak-anak dan pemuda di Bima. Mereka dididik menjadi juru dakwah sekaligus menjadi kader-kader pergerakan.

Pada tahun 1931 Ruma Bicara (Mangkubumi) Abdul Hamid bersama Abdul Wahid Karim Muda tokoh Muhammadiyah kelahiran Sumatera Barat, mendirikan sekolah agama Madrasyah Darul Tarbiyah di kota Raba (Tajib, 1995). Pada tiga tahun berikutnya (1934) didirikan lagi madrasah yang bernama Darul Ulum Bima yang berlokasi di Kampung Suntu, dipimpin oleh Haji Abdurrahman Idris yang sudah lama belajar di Mekkah. Islam bukan hanya sebagai agama yang dianut melainkan sebagai basis ideology perjuangan Sultan yang dibantu oleh Lembaga Syara Hukum. Lembaga ini berperan mengembangkan kualitas dan kuantitas sekolah agama dan rumah-rumah ibadah (mesjid dan langgar) (Ismail, 2004a). Sesuai dengan perkembangan politik pada masa itu, maka tujuan pendidikan bukan saja untuk meningkatkan kecerdasan dan keterampilan, tetapi juga bertujuan untuk mencetak kader-kader militan dan berani, terutama dalam menghadapi pemerintahan Kolonial Belanda.

\section{c. Muhammadiyah.}

Perkumpulan Muhammadiyah didirikan di Bima pada tahun 1937 yang di pelopori oleh Muhammad Idris Jafar, Abdulmuthalib dan Muhammad Hasan penilik sekolah (Tajib, 1995). Kegiatan Muhammadiyah mengarah kepada amal ma'aruf nahi mungkar melalui pengajian. Lomba pidato diselenggarakan untuk meningkatkan keterampilan para juru dakwah yang sanggup berbicara dengan hati nurani masyarakat Bima. Pada bidang politik tidak kelihatan pada Muhammadiyah. Perkembangan Muhammadiyah maju dengan pesat terutama pada kalangan kaula muda. Para kader Muhammdyah ditandai dengan seragam berdasi hijau yang bertuliskan lambang Muhammadiyah aktif melakukan kegiatan sosial kemasyarakatan. Tidak hanya laki-laki yang terdapat pada kegiatan Muhammadiyah, melainkan ada perkumpulan perempuan Muhammadiyah yaitu Aisyah tidak ketinggalan dibentuk yang dipelopori oleh Nona Siti Hawa Tokalodokang yang berdiri sejak tahun 1942. Pengurus Aisyah Bima 
Sumiyati

Kondisi Politik di Kesultanan Bima (1915-1950)

membuka sekolah rendah Muhammadiyah di desa Pane. Kemudian dipindahkan di kampung Ranggo.

\section{d. Persatuan Islam Bima}

Sultan Muhammad Salahuddin memberikan restu kepada perkumpulan persatuan Islam Bima. Maka dari itu persatuan Islam Bima menghimpun para kalangan muda dan tua serta para pemuka masyarakat, dari persatuan penuntut ilmu dan Muhammadiyah khususnya dibentuk perkumpulan persatuan Islam Bima. Tujuan Persatuan Islam Bima melanjutkan usaha pada bidang pendidikan yaitu mencerdaskan masyarakat dari semua golongan. Kegiatan yang dilakukan oleh Persatuan Islam Bima, rupanya Belanda masih mencurigai persatuan Islam Bima dengan komposisi kepengurusan sama seperti komposisi kepengurusan Serekat Islam yang telah dibubarkan oleh Belanda. Kontrolir Bima minta kepada Sultan untuk tidak melaksanakan ketetapan itu dengan alasan bahwa masalahnya mencampuri urusan kewajiban agama. Sultan Muhammad Salahuddin mengadakan musyawarah dengan majelis hadat bersama pengurus Persatuan Islam Bima. Dalam musyawarah itu bersepakat untuk menolak permintaan Kontrolir Bima. Keputusan hasil musyawarah disampaikan kepada Residen Timur dan daerah bawahannya di Kupang, untuk meminta pertimbangan lebih lanjut. Residen membenarkan ketetapan pengurus Persatuan Islam Bima dengan mengatakan tidak bertentangan dengan ajaran agama Islam.

\section{e. Partai Indonesia Raya (Parindra)}

Partai Indonesia Raya membentuk sebuah cabang di daerah Bima pada tahun 1939 yang bertujuan untuk mencapai Indonesia mulia. Pendiri partai Indonesia Raya kebanyakan orang dari Jawa yang menetap di Bima sebagai guru sekolah Gubernemen seperti Sutikno, Citro Sudarno, Siswo Suharto dan Piet Sukarno. Sedangkan dari Bima antara lain, M. Amin Dae Emo, Hasyim Sanggar, Yahya Teta Ani dan Husen Dae Mbee. Tokoh Partai Indonesia Raya yaitu Sukarjo Wiryopratono datang ke Bima untuk menyelesaikan masalah anggota Parindra yang ditangkap oleh Belanda yaitu M. Amin Daeng Emo dan Yahya Teta Ani. Atas anjuran Kontrolir Belanda Sultan Muhammad Salahuddin tidak berkenan untuk menerima Sukarjo Wiryopratono di Istana. Parindra tidak lama bertahan, sebagian dari pengurusnya melanjutkan perjuangan dalam membentuk lain yaitu Rukun Tani di Tente dengan tujuan untuk melanjutkan perjuangan untuk meniadakan kerja paksa dan kerja Rodi. Rukun Tani mempunyai nasib yang tidak jauh berbeda dengan Parindra yang umurnya tidak lama karena diawasi terus oleh Belanda dan akhirnya dibubarkan. 


\section{f. Nahdatul Ulama.}

Sultan Muhammad Salahuddin adalah salah seorang yang menganut ajaran Ahli Sunnah Wal Jamaah. Untuk memperkaya khasanah perkumpulan keagamaan Sultan mengundang Syekh Syehab (Ismail, 2008) anggota pengurus besar Nahdatul Ulama (NU) di Batawi untuk melakukan dakwah keliling di Kerajaan Bima, dan pada akhirnya perjalanan dakwah itu dibentuklah suatu perkumpulan sosial keagamaan yaitu Nahdatul Ulama. Kegiatanya melakukan dakwah dan pengajian, Nahdatul Ulama membentuk organisasi kepanduan Ansor yang dipimpin oleh M. Hasyim alias Ruma Sangga, M. Saleh Ntobu dan Ruma Aye. NU (Nahdatul Ulama) yang semula merupakan organissasi keagamaan yang bergerak di bidang dakwah dan pendidikan pada tahun 1950, berubah statusnya menjadi organisasi politik, ikut direstui oleh Sultan Muhammad Salahuddin.

\section{g. Kependudukan Jepang di Bima}

Bunyi letusan dan ledakan perang pasifik semakin dekat terdengar di Bima. Pasukan payung Bala Tentara Dai Nippon menduduki Tarakan dan Makassar. Penembakan yang meledakan terminal Bensin di pulau Kambing serta penembakan pelataran istana Bima oleh pesawat Jepang merupakan tembakan periangatan dan pemberitahuan bahwa pertahanan Hindia Belanda bagian timur sudah ditaklukan oleh Jepang pada awal tahun 1942. Keadaan yang sebenarnya semakin jelas setelah pada tanggal 9 Maret 1942 panglima tertinggi pasukan Hindia Belanda bersama Gubernur Jendral Hindia Belanda menyerah kepada Jepang di Kalijati. Pada tanggal 5 April 1942, merupakan suatu hari yang direncanakan oleh para laskar untuk melakukan aksi perampasan kekuasaan. Di Bima, perkumpulan Pemuda menyusup kepemerintahan lokal karena Belanda mempertahankan kekuasaannya di wilayah ini. Para pemuda ini menangkap beberapa pegawai Belanda pada tanggal 5 Mei 1942. Disini persatuan pemuda memainkan peranan penting, yang berkembang sebagai elemen nasionalis dan revolusioner.

Pada malam hari menjelang hari yang direncanalkan itu, Aritonang bersama dengan teman-temannya serdadu Koninklijk Nederlandsch Indic Lege (KNIL) yang berjiwa nasionalis menawan komandannya seorang kapten berkebangsaan Belanda, melucuti senjata serdadu KNIL lainnya. Setelah itu mereka membagi diri kesasaransasaran lainnya yang meliputi; Pusat alat komunikasi di Kota Bima, Tangsi polisi Raba, Rumah para pejabat Belanda, kantor sentral Telefon Raba, radio kamar bola, dan Stasiun Tolomundo. Kemudian berusaha menahan yang ingin melarikan diri supaya rencana tidak di ketahui oleh Belanda (Tajib, 1995). Melihat pemaparan tersebut, dapat diketahui bahwa gerakan atau aksi yang dilakukan oleh para serdadu KNIL yang 


\section{Sumiyati}

Kondisi Politik di Kesultanan Bima (1915-1950)

membelot ini tersusun rapi, dan tentunya telah diperhitungkan dengan tepat, cermat, dan teliti. Setiap tempat yang menjadi sasaran dalam aksi perebutan tersebut dikomandoi oleh seorang pemimpin laskar di setiap regunya. Seperti ditangsi Polisi Raba, didalam melakukan aksi ini dipimpin oleh Aritonang, sementara di pusat alat komunikasi central telefon Raba dan Stasiun Tolomundu dipimpin oleh Muhammad Qasmir.

Aksi perebutan kekuasan yang dilakukan oleh para laskar pada tanggal 5 April 1942 tersebut sangat berhasil, hal ini dilihat dari keberhasilan Laskar menahan beberapa pejabat dan orang-orang penting Belanda seperti : Mr. Hachman (Kontrolir Bima), Karsedon (Agen KPM), Kemper (Inspektur Polisi), Van der Capellen (Hoofd Opzieghter Bima), Muller (Hoofd Cipier Bima), dan Damal Adu (Mantri Polisi). Ada juga yang lolos dan berhasil melarikan diri diantaranya : Pons (Administratur AVB=BRI), J.W. Ros (BochArchitecs Bima) atau yang lebih dikenal dengan Tuan Jati Komba, serta H. E. Haak (Assinten Residen Sumba-Sumbawa) yang kebetulan pada saat aksi berada di Sumbawa. Di Sumbawa besar sedang dikembangkan isu bahwa Sultan Bima sudah ditangkap beserta orang-orang Belanda dan dipenjarakan. Asisten Residen H. E. Haak minta bentuan Capier (Polisi) Serta Serdadu KNIL untuk melepaskan Sultan Bima dan Orang-orang Belanda dari tangan pemberontak. Sultan Sumbawa pun terpancing isu tersebut. Polisi Sumbawa-pun dikerahkan, serangan balik ke Bima akan dilancarkan pada tanggal 12 April 1942.

Sebelum pergi menghadang di Sori Utu, pada waktu malam para laskar berkumpul bersama Sangaji Mbojo untuk membicarakan apa yang harus diperbuat. Setelah itu, Sangajipun melepas dengan sapaan sebagai berikut: "Lembo ade paja sara saramu, su'u pu sawa`u siapu sawale, parenta ra nggahi sara diru 'u ba dou mamboto labo dana" (Tajib, 1995). (Sabar dan pasrahlah, junjung tinggi sekuat tenaga, tahan sedapatdapatnya perintah pemerintah untuk orang banyak dan tanah leluhur). Dalam persiapan untuk menyongsong kedatangan pasukan dari sumbawa tersebut, menghasilkan kesepakatan untuk membuat suatu laskar penangkal, adapun laskar penangkal yang dimaksud dalam rapat komite aksi bersama Sultan Bima tersebut adalah suatu laskar inti yang terdiri dari serdadu KNIL dan polisi yang berjiwa nasionalis yang dipimpin oleh Aritonang dan dibantu pula oleh pemuda-pemuda pergerakan yang tergabung dalam laskar Bima. Laskar ini dipersiapkan untuk menghadang kedatangan pasukan dari Sumbawa dimanapun mereka bertemu, tanpa harus menunggu sampai mereka tiba di kota.

Setelah dipersilahkan oleh Sultan, laskar Bima bergerak melintasi jalan lintas Sumbawa-Bima, Hingga pada subuh hari tepatnya di Sori Utu mereka melihat konvoi kendaraan dari arah yang berlawanan. Para Laskarpun mengatur siasat guna melakukan perlawanan. "Dimulai waktu subuh itu terjadi baku tembak antara Laskar 
Bima dengan pasukan sumbawa, yang menyebabkan La Dri (Idris Hakim) meninggal" (Tajib, 1995). Keterangan lain tentang peristiwa tersebut dapat disimak pada petikan kalimat berikut:

"Pada malam buta, pasukan laskar Bima tiba di lembah Hutan Sateppe di Sori Utu. Mereka berhenti di ujung jembatan, kemudian mengatur penyerangan di ujung timur jembatan untuk melakukan perlawanan. Di tengah gelapnya malam, terlihat sorotan lampu dari kejauhan memasuki ruas jalan menuju Banggo, hingga menjelang dini hari, pasukan Sumbawa mendekati jembatan dengan melaju sangat pelan dan laskar Bima tidak membuang-buang waktu, dan langsung melancarkan tembakan. baku tembakpun terjadi hingga menjelang siang hari.

Ketika pertempuran sedang berlangsung sengit, laskar Bima tiba-tiba menghentikan pertempuran, sembari mengutus salah seorang dari mereka bertemu dengan pimpinan pasukan dari Sumbawa perihal perundingan antara kedua belah pihak dalam rangka penghentian tembak menembak. Utusan dari laskar Bima ternyata berhasil bertemu dengan pimpinan pasukan Sumbawa, dan kemudian kedua belah pihak bersepakat untuk mengadakan perundingan. perundingan itupun pada akhirnya mengahsilkan kesepakatan untuk menghentikan pertemputan. Kedua belah pihak akhirnya insyaf, setelah utusan pimpinan laskar Bima menjelaskan sebab musabab terjadinya pertempuran itu, yang ternyata hanyalah politik devide et impera (adu domba) yang dilakukan oleh pemerintah Hindia Belanda" (Tajib, 1995).

Sementara itu, dipihak pasukan Sumbawa juga dikatakan terdapat korban, yang diantaranya berkebangsaan Belanda (yang ketika pertempuran sedang berlngsung ditinggalkan oleh pasukan Sumbawa) yang diangkut oleh laskar Bima bersama korban lainnya, seperti Idris Hakim dan M. Amin Dae Emo. Setelah terjadi beberapa insiden (perlawanan) terhadap pemerintah Kolonial Belanda antara lain pada tanggal 5 April 1942 yang ditengarai oleh komite aksi rakyat Bima (Laskar Bima), Belanda-pun akhirnya meninggalkan Kerajaan Bima. Dengan demikian pengaruh dan kekuasaannya-pun berakhir. atau dengan kata lain rakyat Bima telah bebas dari belenggu penjajah yang telah lama memeporak-porandakan tatanan kehidupan sehari-hari dan berbagai dampak lainnya yang ditimbulkan selama penjajahan Belanda di Bima.Kendati demikian, apakah berbagai ancaman dan tantangan yang dihadapi masyarakat Bima telah berakhir, atau justru akan memasuki fase baru dengan pelaku yang berbeda, namun tujuannya sama yakni mengadakan eksploitasi terhadap penduduk Bima.

Dibentuknya sebuah Pasukan keamanan yang terdiri dari polisi lapangan dan anggota Ansor dan Hizbul Wathan. Pasukan ini Selanjutnya disebut sebagai bala 


\section{Sumiyati}

Kondisi Politik di Kesultanan Bima (1915-1950)

tentara kerajaan. Setelah kedatangan Jepang di Sumbawa Besar pada tanggal 14 Mei dengan tiba di Bima pada tanggal 17 Mei 1942. Para pemimpin lokal seperti wakil Sultan Muhammad Salahuddin yang diutus olehnya yaitu Demung Alas, Demung Seteluk dan pemimpin desa Mapin menyambut kedatangan para tentara Jepang yang dipimpin oleh Kolonel Hari Aci dan Letnan Saito. Tujuan menyambut tersebut adalah untuk memastikan kedudukan mereka sendiri, serta agar mereka dapat mempertahankan hartanya jika bekerja sama dengan Jepang. Lama-kelamaan penduduk pribumi ikut terpengaruh sehingga kedatangan Jepang tidak hanya disambut oleh para elite lokal, namun juga seluruh penduduk. Setelah itu pasukan Jepang melanjutkan perjalanan ke Bima di bawah pimpinan Kolonel Hari Aci. Sultan Muhammad Salahuddin serta Penduduk Bima menyambut para tentara Jepang di Kerajaan Bima. Setelah itu Sultan menyerahkan para tahanan yaitu orang-orang Belanda kepada tentara Jepang. Pada masa itu Sultan dihormati oleh penduduknya.

\section{Peran Sultan Muhammad Salahuddin Dalam Memperjuangkan Kemerdekaan.}

Ketika pemerintah Hindia Belanda menyerah pada tanggal 8 Maret 1942 di Kalijati kepada tentara Militer Jepang, maka tamatlah riwayat penjajahan yang dilakukan oleh Kolonial Belanda di Bima yang dimulai pada tahun 1905. Pada tahun 1942 di Bima membentuk suatu komite aksi penangkapan Belanda, Sultan Muhammad Salahuddin sangat mendukung gerakan itu. Banyak pasukan Belanda di Bima berhasil ditangkap. Melalui serangan 5 April 1942, pemerintahan Kerajaan Bima dibawah pimpinan Sultan Muhammad Salahuddin berhasil merebut kekuasaan penuh dari tangan pemerintah Hindia Belanda di Bima. Bebaslah sudah Kerajaan Bima dari rantai belenggu imperialisme Belanda. Dengan kedatangan tentara Jepang dirasakan lebih baik karena kedatangan tentara Jepang sudah pasti tidak dapat dibendung, dengan demikian Belanda akan dihadapi oleh Jepang. Pada tanggal 17 Juli 1942, tentara Jepang sudah mendarat di pulau Sumbawa yang dipimpin oleh Kolonel Saito. Kolonel Saito bersikap simpatik sehingga rakyat Bima menyambutnya sebagai saudara tua yang baik, namun itu tidak bertahan lama, dengan diturunkanya Bendera Bima dan digantikan dengan bendera Jepang membuat Sultan marah. Mulainlah penjajahan baru yang dilakukan oleh tentara Jepang.

Kekejaman pemerintahan pendudukan Jepang semakin hari semakin jadi. Sementara itu, Bima pun menjadi sasaran pemboman Tentara Sekutu sehingga pemerintahan Kerajaan dipindahkan ke kampung Dodu. Pemboman yang dilakukan oleh tentara Jepang di pasar Bima pada tahun 1944 mengakibatkan rakyat Bima banyak yang meninggal. Pada masa kependudukan Jepang di Bima, bahan makanan pokok sulit didapat karena diangkut habis untuk keperluan logistik tentara Jepang. Penduduk Bima banyak yang dijadikan Romusha dan kaum wanita diminta untuk dijadikan 
wanita penghibur tentara Jepang. Dalam menghadapi hal yang terakhir ini menyinggung perasaan dan kehormatan pemerintah beserta rakyat Kerajaan Bima. Menanggapi permintaan Jepang untuk menyediakan wanita pelayan. Sultan Muhammad Salahuddin membicarakanya dengan jeneli rasanaE yaitu Abdul Muthalib. Setelah itu Sultan menolak permintaan tentara Jepang untuk menyediakan wanita pelayan (jugun ianfu) (Tajib, 1995).

Tiada hari yang penuh kepanikan bercampur garang selain dari pada hari-hari sesudah kejadian itu bagi rakyat Bima, terutama bagi para orang tua yang mempunyai anak gadis. Sultan Muhammad Salahuddin mengambil langkah-langkah pencegahan untuk menghadapi kemungkinan yang tidak diinginkan. Sultan menyarankan dan menganjurkan kepada para orang tua agar segera mengawinkan anak gadis antara keluarga atau dengan jejaka yang dianggap pantas. Perkawinan pada masa itu dikenal dalam masyarakat Bima adalah nika baronta (kawin berontak) (Ismail, 2004a). Sikap tegas yang dilakukan oleh Sultan Muhammad Salahuddin bersama rakyat Bima memaksa Jepang mengurungkan niatnya. Dalam usahanya untuk tidak menyediakan wanita pelayan Sultan Muhammad Salahuddin berhasil dengan melakukan penjagaan ketat terhadap wanita-wanita Bima dan menyuruh masyarakat setempat untuk menikahkan anaknya. Dengan usaha seperti itu, tentara Militer Jepang mengurungkan niatnya dan mendatangkan wanita-wanita dari luar daerah Bima.

Pada tahun 1944 perang pasifik berbalik arah. Di laut dan di darat Jepang di hancurkan oleh Tentara Sekutu. Dalam keadaan kritis ini Jepang menjanjikan kemerdekaan kelak kemudian hari setelah selesai perang. Selama masa pendudukan Jepang, Sultan Muhammad Salahuddin melaksanakan kebijakan pemerintah yang tidak melawan arus kekuasaan pemerintah Militer Jepang untuk menghindari korban yang sia-sia terutama rakyat. Kebijakan tersebut berlandaskan keyakinan bahwa sekali waktu kelak melalui perjuangan yang diperhitungkan kemerdekaan pasti akan tercapai. Setelah Jepang bertekuk lutut kepada Sekutu, kesempatan itu tidak disia-siakan oleh para pejuang pergerakan yaitu Soekarno dan Hatta dengan memproklamasikan Kemerdekaan Republik Indonesia pada tanggal 17 Agustus 1945.

\section{Periode akhir Sultan Muhammad Salahuddin}

Pada tanggal 14 Agustus 1945 beberapa tokoh masyarakat dan pergerakan telah mengetahui adanya penyerahan Jepang, karena Sekutu telah menghancur leburkan Hirosima dan Nagasaki, sehingga membuat Jepang menyatakan menyerah kepada Sekutu dan membuat Jepang menghentikan perang di semua medan pertempuran. Namun berita kekalahan Jepang terhadap Sekutu sangat lambat diketahui seluruh 


\section{Sumiyati}

Kondisi Politik di Kesultanan Bima (1915-1950)

rakyat Swaparaja Bima. Akan tetapi lama kelamaan rakyat Bima mengetahui tentang kekalahan Jepang dari kapten Hesino (Inspektur PETA) yang telah membocorkanya.

Selain itu informasi kemerdekaan ini diperoleh secara resmi oleh Sultan Muhammad Salahuddin dari utusan Gubernur Sunda Kecil I Gusti Ketut Puja, yang mengirim delapan orang pelajar dari Bima yang belajar di Bali antara lain Muchtar Sulaeman, M. Ali, Majid Datuk dan M. Nur Husein. Di samping menyampaikan informasi tentang kemerdekaan mereka juga menyampaikan bahwa telah di bentuk Komite Nasional Indonesia Sunda Kecil yang berkedudukan di Singaraja (Bali) yang diketahui oleh Ida Bagus Manuaba, supaya segera membentuk Komite Nasional (Abiddin, 2005).

Berdasarkan keterangan tersebut beberapa pemuka masyarakat dan tokoh pergerakan dengan penuh keyakinan pada bulan Agustus 1945 mendatangi pimpinan tertinggi pemerintah Militer Jepang Sumbawa Timur Jendral Mayor Tanaka yang berada di Raba untuk meyerahkan kembali pemerintahan kepada Kerajaan Bima karena Jepang telah kalah perang dan menyerah kepada Sekutu. Dengan didukung oleh situasi yang tidak menentu pada waktu itu, akhirnya Jendral Mayor Tanaka menyerahkan kekuasaan pemerintahan Menseibu (urusan pemerintahan sipil) kepada pemerintah Kerajaan Bima pada tanggal 31 Agustus 1945 (Abiddin, 2005). Dengan demikian sejak tanggal tersebut pemerintah Kerajaan Bima secara de fakto memegang kedaulatan atas wilayah Kerajaan Bima yang meliputi Bima dan Dompu. Para pejuang pergerakan Indonesia yang tergabung dalam lembaga-lembaga pergerakan, maka revolusi negara Indonesia akan dimulai. Revolusi yang dimaksud adalah perjuangan rakyat Bima. Pusat kekuatan perjuangan rakyat adalah di Tente, pengambilan wilayah Tente sebagai sentral pergerakan perjuangan di Bima dikarenakan tempat Tente tersebut sangat strategis, karena merupakan jalur dari kejenelian-kejenelian yang ada di Bima sehingga hubungan komunikasi sangat mudah dijangkau.

Informasi kemerdekaan yang telah menyebar luas di daerah Bima memberikan semangat dan rangsangan baru bagi rakyat Bima untuk melanjutkan perjuangan yang sudah dimulai. Insiden demi insiden telah terjadi terus antara rakyat dengan tentara Jepang yang melakukan perjuangan blockade (perjuangan di tiap-tiap daerah) untuk merampas senjata dan membagi kekuatan Jepang. Perkembangan lebih lanjut di Bima dibentuk Barisan Keamanan Rakyat (BKR) yang anggotanya berasal dari Pasukan Pembela tanah Air (PETA) dan Haiho. Yang menjadi komandan dalam pasukan itu adalah Putra Abdul Kahir anak dari Sultan Muhammad Salahuddin. Para pemuda yang tidak ingin menjadi BKR, membentuk laskar sendiri yaitu Angkatan Pemuda Indonesia (API) yang berpusat di desa Tente dan dipimpin oleh M. Tayib Abdullah.

Pada tanggal 29 Desember 1945 para pejuang yang ada di kejenelian Belo, Woha dan Monta mengepung gudang senjata milik Jepang yang ada di Samili dibantu oleh 
sejumlah kepala desa (Galara) bersama-sama dengan rakyatnya. Walaupun sejumlah pemuda dan rakyat banyak terbunuh dalam pertempuran melawan tentara Jepang (Abiddin, 2005). Senjata-senjata yang mereka peroleh dari hasil rampasan tersebut semuanya disimpan di Kalate Cenggu (kantor kejenelian Belo), atas perintah pimpinan tertinggi TKR Abdul Kahir (Anak Sultan Muhammad Salahuddin), senjata tersebut tidak lama disimpan, sehingga dengan segera harus dibagi-bagikan kepada para pejuang yang sudah dilatih memakai senjata api. Mereka itu umumnya mantan anggota Heiho, Sainendan, Peta dan Keibodan. Pembagian senjata segera dilakukan karena dikhawatirkan Tentara Sekutu dan NICA akan mendarat dalam waktu yang tidak terlalu lama lagi di kabupaten Bima.

Peristiwa demi peristiwa berjalan dengan cepat pada pertengahan bulan Desember 1945. Dalam bulan desember pemerintah Kerajaan Bima menghadapi Jepang dan NICA. Pemerintah Militer Jepang mulai memperlihatkan gigi untuk kepentingan Sekutu, meratakan jalan untuk kedatangan NICA. Karenanya suasana politik semakin hangat serta didukung kegiatan militer. Pada tanggal 30 Oktober 1945, Sultan Muhammad Salahuddin sepakat dengan Komite Nasional Indonesia Daerah (KNID) Bima untuk melakukan upacara resmi pengibaran bendera merah putih yang akan dilaksanaka di Istana Bima. Dalam pelaksanaan upacara pengibaran bendera merah putih dihadiri banyak lapisan masyarakat termaksud utusan-utusan dari kejenelian. Pada tanggal 24 November 1945, Sumbawa Ken Karikan Wataksuki datang ke Istana Bima dengan maksud meminta kembali kekuasaan yang pernah diserahkanya. Sultan Bima menolak permintaan tersebut. begitupun dengan KNID Bima menolah kedatangan Jepang. KNID Bima membentuk suatu dewan pemerintahan yang berkedaulatan rakyat di markas KNID Bima dan Raba, dimana Sultan Muhammad Salahuddin duduk sebagai pucuk pimpinan, dan Raja Muda pun duduk sebagai Menteri Pertahanan. Disini jelas sekali sikap Sultan Salahuddin yang tidak lagi menganggap dirinya sebagai pimpinan sebuah kerajaan, namun sebagai pimpinan daerah yang merupakan wilayah Republik Indonesia.

Sementara itu Mustamin Abdurahman komandan TKR sektor Sape memberitaukan kepada pimpinan pemuda di Wawo agar membuat barikade pada tikungan jalan sebelah utara desa Ntori untuk menghadang bala Bantuan Jepang ke Sape. Pada tanggal 2 Januari 1946 laskar TKR Sape menyerang markas Jepang di Sape untuk merebut senjata. Pada awal tahun 1946, Netherland Indies Civil Administration (NICA) mendarat di Sumbawa besar. Setelah itu NICA memberitahukan kepada Sultan Bima agar menerima NICA dengan baik dan tanpa perlawanan. Setelah itu Sultan merundingkan dengan tokoh-tokoh KNID, API, TKR, dan tokoh-tokoh pemuka masyarakat lainya, bagaimana harus menghadapi ancaman Pimpinan Tentara Sekutu 


\section{Sumiyati}

Kondisi Politik di Kesultanan Bima (1915-1950)

itu yang akhirnya diambil keputusan bahwa Kerajaan Bima tidak akan menerima NICA. Akibatnya, kapal perang Tentara Sekutu mendarat diteluk Bima yang dipimpin oleh Brijen G.H Dyke dari Australian Military Forces. Sultan Muhammad Salahuddin menyampaikan dari hasil musyawaranya di Istana dengan tokoh-tokoh KNID, API, TKR, dan tokoh-tokoh pemuka masyarakat, bahwa Kerajaan Bima Menolak dengan keras kedatangan Tentara Sekutu. Akhirnya perundingan dilaksanakan di atas kapal perang Australia yang berada di perairan Teluk Bima. Delegasi Kerajaan Bima dipimpin langsung oleh Sultan Muhammad Salahuddin. Dalam perundingan antara Sultan dengan pihak Sekutu, Sultan bersikeras tidak mau menerima NICA, sementara pihak Sekutu bersikeras agar NICA diterima dan benderanya dikibarkan. Sultan Muhammad Salahuddin juga bersikeras bahwa Kerajaan Bima berdiri di belakang Republik dan hanya bendera merah putih yang boleh dikibarkan. Dalam suasana perundingan Sultan diancam oleh pihak Sekutu dengan tuduhan sebagai penjahat perang, sementara itu, senjata penggempur diarahkan di Kerajaan Bima. Sultan tidak bisa berbuat apa-apa, dan Sekutu dan NICA masuk di Kerajaan Bima dan terus ke Raba untuk menangkap anggota TKR, Laskar, anggota KNID, dan para Penduduk yang menolak kedatangan Sekutu dan NICA.

Pada tanggal 3 Januari 1946 kapal Sekutu meninggalkan perairan teluk Bima, namun pada tanggal 5 Januari 1946 kapal perang Sekutu muncul lagi dalam jumlah yang besar di perairan teluk Bima. Pada tanggal 8 Januari 1946 secara tiba-tiba muncul pasukan Jepang mengepung markas API di Tente dan menangkap semua yang berada disitu. Mereka dikumpulkan dalam pasar Tente untuk dihukum karena telah melakukan penyerangan terhadap markas Jepang dan merampas senjata. Manuver kapal-kapal perang Sekutu dan serbuan tentara Jepang tersebut sebagai gerakan intimidasi sebelum perundingan yang sebenarnya dimulai dengan kata lain perang urat saraf sudah dimulai. Di darat Jendral Mayor Tanaka bertindak serasi dengan menekan pemerintah Kerajaan Bima paling tidak selaku penghubung sekaligus pelaksana perintah Sekutu di darat.

Antara Sultan Muhammad Salahuddin dengan Jendral Mayor Tanaka berbeda pendapat tentang tempat pertemuan dengan panglima balatentara Australia yang akan datang di Bima. Pada tanggal 11 Januari 1946 ditunjuk delegasi yang terdiri dari pejabat pemerintah kerajaan dan pimpinan Komite Nasional Indonesia daerah Bima selaku utusan pemerintahan Kerajaan Bima. Yang dirundingkan adalah kedudukan tentara Jepang, keamanan serta kedatangan NICA. Tiada keputusan pokok dapat disepakati dalam perundingan kala itu. Masing-masing pihak berpegang teguh pada pendirian masing-masing. Perundingan pada hari pertama tidak membawa hasil. Pada tanggal 12 januari 1946 Brigadir Jendral Dyke mengeluarkan panggilan yang disertai ancaman akan menggempur Bima, bila Sultan Muhammad Salahuddin tidak datang ke kapal 
untuk berunding. Sultan harus memimpin sendiri delegasi Kerajaan Bima dalam perundingan akan berlangsung pada hari itu juga.

Selama perundingan berlangsung di atas kapal Sekutu yang dibicarakan hanya satu masalah pokok yaitu Sultan Muhammad Salahuddin harus menerima kedatangan NICA serta menaikan bendera Belanda. Titik klimaks dari perundingan itu adalah disaat Brigadir Jendral Dyke memberikan ultimatum kepada delegasi Kerajaan Bima bahwa bendera Belanda harus dikibarkan pada hari itu juga dan bendera merah putih tidak boleh dikibarkan bahkan orang yang mengibarkan bendera merah putih dianggap sebagai perampok. Namun dalam perundingan tersebut Sultan Muhammad Salahuddin belum mau menerima ultimatum Sekutu. Pemerintah Kerajaan Bima pimpinan Sultan Muhammad Salahuddin terus dipaksa oleh pihak Sekutu (Australia, NICA) dan Jepang agar menerima kedatangan Sekutu. Akhir dari keputusan perundingan tersebut membuat Sultan Muhammad Salahuddin terpakasa menerima kedatangan pihak Sekutu karena diancam sebagai penjahat perang, telah mebuat makar dengan melakukan perebutan kekuasaan dari tangan pemerintahan Hindia Belanda pada tahun 1942. Pimpinan tertinggi balatentara Australia bersama pimpinan NICA kini dapat bernapas panjang, karena Kerajaan Bima yang ingin digenggam baru terpenuhi pada tanggal 12 Januari 1946.

Beberapa hari sesudah pemerintah NICA berkuasa di Bima, Kapten Meinders selaku komanda Koningkrijke Nederland Indische Leger (KNIL) beserta serdadunya mulai melakukan penangkapan pimpinan Laskar, anggota KNI, pimpinan laskar API dan pegawai serta penduduk dengan tuduhan anggota gerombolan ekstremis untuk ditahan ke markas Jepang. Banyak dari anggota perjuangan ditangkap dan dianiaya. Dalam upaya NICA menduduki Kerajaan Bima, tentara Australia untuk keduakalinya mengunjungi Bima. Kunjungan satuan tugas tersebut dapat diartikan sebagai tekanan diplomatik supaya Sultan Bima harus mentaati pemerintah Militer Jepang sebagai pengamanan ketertiban umum.

\section{Gagalnya Politik Devide et Impera dan terbentuknya Swapraja Bima.}

Dunia terjaga dari propaganda Belanda yang menuduh adanya gerombolan ekstermis di Indonesia. Dunia mempertanyakan kebenaran dari propaganda Belanda terhadap Republik Indonesia Proklamasi 17 Agustus 1945. Untuk meyakinkan kembali agar opini dunia berpihak kepada Belanda Van Mook sebagai pejabat tertinggi Kerajaan Belanda di Indonesia dengan giat melakukan upaya memecah belah kesatuan Republik Indonesia. Pejabat tertinggi Kerajaan Belanda Van Mook mengundang kepala pemerintah di daerah pendudukan untuk mengadakan konferensi Malino. Konferensi di Malino membuahkan keputusan atau perintah untuk membentuk negara-negara. 


\section{Sumiyati}

Kondisi Politik di Kesultanan Bima (1915-1950)

Dengan negara boneka, Belanda meyakinkan dunia bahwa proklamasi kemerdekaan Republik Indonesia tidak didukung oleh rakyat Indonesia dengan maksud mendesak posisi Republik Indonesia dalam perang diplomasi.

Sejak awal tahun 1946 Negara Kesatuan Republik Indonesia menghadapi masalah yang berat. NICA dengan segala macam cara berusaha memecah belah persatuan bangsa. Selain dapat rongrongan dari NICA, timbul pula masalah yang dapat mengganggu kestabilan politik dan pemerintahan yang datang dari golongan oposisi ialah adanya usaha kudeta. Situasi keamaanan dan politik yang rawan itu, dimanfaatkan oleh Van Mook yang selaku Gubernur Letnan Jendral, dengan membujuk penguasa-penguasa di daerah-daerah untuk memisahkan diri dengan Negara Kesatuan Republik Indonesia. Dalam usaha membentuk negara-negara boneka sudah terbilang berhasil yang terbilang amat bertentangan dengan aspirasi dan suara hati rakyat. Tetapi apabila rakyat melakukan perlawanan, NICA secara kejam mematahkan dengan kekerasan senjata dan politik adu domba.

Selain dengan menggunakan kekuatan militer Letnan Gubernur Jendral Van Mook menggunakan diplomasi untuk memecah belah persatuan. Melalui konferensikonferensi di daerah-daerah Van Mook berhasil membujuk penguasa-penguasa di daerah-daerah untuk memisahkan diri dari Negara Kesatuaan Republik Indonesia dan berhasil mendirikan negara boneka. Politik Devide et Impera (politik adu domba) ikut mempengaruhi perkembangan keamanan dan politik di Kerajaana Bima. Perjanjian Linggarjati yang ditanda tangani pada tanggal 15 November 1946 yang memberikan pengakuan de fakto keberadaan Republik Indonesia di pulau Jawa. Hal ini memberikan dampak terhadap tahanan di Bima. Assisten residen membentuk suatu komisi untuk memeriksa para tahan politik atau tahanan merah putih. Dengan adanya perjanjian Linggarjati serta terciptanya Negara Indonesia Timur keadaan politik di Bima mulai melonggar. Para tahanan merah putih dibebaskan. Kesempatan untuk berkumpul dan berserikat diberi kebebasan yang terikat. Kesempatan ini dipergunakan dengan baik secara terbuka dan kegitan bawah tanah untuk melanjutkan perjuangan Indonesia merdeka.

Diterimanya Perjanjian Linggarjati pada tanggal 15 November dapat diartikan sebagai pengakuan politik Internasional, yang mengakui de fakto keberadaan dan kekuasaan Republik Indonesia, sebaliknya juga memberikan pengakuan terhadap daerah pendudukan Belanda. Adanya perjanjian Linggarjati serta terciptanya Negara Indonesia Timur keadaan politik di Bima mulai melonggar. Para tahanan merah putih mulai dibebaskan. Dengan kelonggaran politik dan dengan peraturan pemerintah Negara Indonesia Timur (NIT), pemerintahan di pulau Sumbawa dijalankan oleh Dewan raja-raja yang Sultan Bima sebagai ketua dan Sultan Sumbawa sebagai anggota. 
Akibat dari konferensi Linggarjati, maka timbul reaksi pro dan kontra di kalangan rakyat Indonesia. Rakyat melakukan perlawanan, Belanda mematahkan perlawanan rakyat dengan agresi Militer I. namun semua tidak membuat rakyat patah semangat untuk melakukan perlawanan terhadap Belanda, dengan semangat rakyat yang gigih membuat Belanda terdesak dan di saat kedudukan terdesak pada tanggal 17 Januari 1948, diadakan lagi perjanjian Renville yang makin memperkecil wilayah dan kekuasaan bangsa Indonesia. Dari rentetan konferensi dan agresi yang dilakukan oleh NICA membuat kedudukan negara Republik Indonesia semakin terancam, walaupun seluruh masyarakat melakukan perlawanan.

Perkembangan berlanjut Pemerintahan Kerajaan Bima pada tanggal 9 Januari 1947 membentuk Raad Bima-Dompu yang merupakan dewan penasehat. Dengan adanya dewan penasehat, pemerintah Kerajaan Bima kembali kepada pemerintahan yang berdasarkan Hukum Hadat dan Hukum Islam. Dengan keputusan pemerintah Kerajaan Bima, dibentuk dan disusun Majelis Tureli yang dipimpin oleh Wazir Abdul Hamid. Sebagai kelengkapan pemerintahan Hadat maka Majelis atau badan hokum Syara' diaktifkan kembali sebagai salah satu komponen Majelis Hadat (Ismail, 2004b). Sultan Merangkap jabatan sebagai Qadi yakni pimpinan tertinggi majelis Syara'. Dengan diberlakunya kembali pemerintahan Hadat maka struktur, perangkat pemerintahan diaktifkan kembali. Pemekaran wilayah Kerajaan Bima yang meliputi Bima dan Dompu dilakukan. Sejak dipulihkan kembali status Kerajaan Dompu dengan melepas Dompu dan kembali pada wilayah asli yang meliputi 10 Kejenelian (Ismail, 2004b).

Dalam menghadapi situasi politik yang serba gelap dan goncang itu, posisi Kerajaan Bima semakin sulit. Kekuatan TKR, API tidak mampu menjawab tantangan yang berat itu. Begitu halnya dengan Sultan dan KNI sebagai pemegang dan pelaksana pemerintahan. Namun dari segi semangat nasional yang menjunjung tinggi persatuan dan kesatuan tetap bergelora dalam dada sanubari rakyat Bima. Politik Belanda di Indonesia semakin mendapat tekanan dari dunia internasional agar pertikaian antara pemerintah Belanda di Indonesia dan pemerintahan Republik Indonesia diselesaikan melalui perundingan. Dalam perundingan itu melahirkan sebuah perjanjian Renville yang ditanda tangani pada tanggal 10 Januari 1948. Dalam perjanjian Renville, membawa perubahan politik Belanda di daerah pendudukan. Kepala pemerintahan setempat yang selama ini dipegang oleh pejabat Belanda sendiri diserahkan kepada Sultan Muhammad Salahuddin. Dengan keputusan tersebut Kerajaan Bima berstatus zelf bestuur (swapraja).

Perubahan kebijakan di daerah pendudukan sesudah perjajian Renville berjalan terus seiring dengan kemajuan yang dicapai di bidang politik dan militer antara 


\section{Sumiyati}

Kondisi Politik di Kesultanan Bima (1915-1950)

Belanda dengan Republik Indonesia. Dalam anggota perwakilan rakyat pulau Sumbawa dipilih melalui pemilihan sistem pemilihan bertingkat. Komposisi keanggotaannya ialah pada Kerajaan Bima 8 orang, Kerajaan Sumbawa 6 orang dan Kerajaan Dompu 3 orang. Sedangkan dari golongan minoritas melalui pengangkatan sebanyak 4 orang. Seirama dengan perubahan tersebut, maka pemerintahan Kerajaan Bima melakukan penyesuaian, pemerintahan Kerajaan Bima mengeluarkan peraturan pembentukan dewan perwakilan rakyat daerah Kerajaan Bima yang beranggotankan 20 orang dengan ketentuan 16 orang dipilih melalui pemilihan sistem pemilihan bertingkat dan 4 orang dari golongan minoritas melalu pengangkatan.

Dalam situasi itulah Sultan Muhammad Salahudin bersama tokoh pemuda, pada tanggal 23 Maret 1948, mendirikan organisasi lokal "Ikatan Qaum Muslimin Indonesia" (IQAM). Dengan susunan pengurus H. Usman Abidin (ketua) dan wakil ketua: M. Idris Jafar, Sekretaris I: M. Saleh Bakry dibantu sekretaris II: Jafar AR, Bendahara: Abdullah Amin Teta Hafsah dengan pembantu masing-masing Nasaruddin dan M. Hasan.Ketika Sultan Muhammad Salahuddin mulai sibuk membenahi keadaan politik dan pemerintahan di Kerajaan Bima, keadaan Indonesia secara keseluruhan sudah mulai berubah. Sultan Salahuddin tidak memutuskan hubungannya dengan Republik di Yogyakarta. Pada tahun 1949, pengurus IQAM menghadiri kongres Al Islami di Yogyakarta untuk berjuang menolak pembentukan negara Republik Indonesia Serikat (RIS), yang diusulkan Belanda. Sultan berusaha untuk bergabung dengan Negara Kesatuan Republik Indonesia (NKRI). Ia mengutus pimpinan KNID Bima, dan Raja Muda Abdul Kahir ke Kongres Al-Islami di Yogyakarta pada tahun 1949 untuk menyampaikan sikap mempertahankan Negara Republik Indonesia.

Pada tanggal 14 April 1949 Belanda mulai melakukan perundingan dengan Indonesia untuk memulihkan perdamaian. Perundingan ini menghasilkan perjanjian Roem-Royen pada tanggal 14 April 1949. Hasilnya dimanfaatkan dan oleh Sultan Muhammad Salahuddin untuk mengadakan pertemuan dengan Sultan Dompu dan Sultan Sumbawa, guna membahas perkembangan politik dan menentukan sikap politik bersama. Keduanya mengirimkan delegasi untuk permusyawaratan federal atau Bijeenkomst Federaale Overleg (BFO) ke perundingan Meja Bundar di Den Haag (Belanda) (Ismail, 2004b). Konferensi Meja Bundar (KMB) berhasil menyelesaikan pertikaian Indonesia dengan Belanda. Konferensi menghasilkan pengakuan kedaulatan kepada Republik Indonesia Serikat. Sultan Bima harus menyesuaikan dengan hasil Konferensi Meja Bundar.

Selain itu pada tahun 1950, Sultan Muhammad Salahuddin mengadakan pertemuan dengan Sultan Dompu dan Sultan Sumbawa untuk membentuk dewan rajaraja sepulau Sumbawa, untuk membuat pernyataan bahwa Sultan Bima, Sultan Dompu dan Sultan Sumbawa ingin bergabung dengan Republik Indonesia. Dewan raja-raja 
federasi pulau Sumbawa yaitu Sultan Bima, Sultan Sumbawa dan Sultan Dompu pada tanggal 11 April 1950, mengadakan pertemuan di Dompu serta mengeluarkan pernyataan bersama melepas diri dari Negara Indonesia Timur (NIT) dan menggabungkan diri dengan Republik Indonesia di Yogyakarta. Penyataan disambut dengan demonstrasi pembubaran Negara Indonesia Timur (NIT). Kerajaan Bima berubah statusnya menjadi daerah Swapraja Bima lengkap dengan dewan perwakilan rakyat daerah Swapraja Bima pada tahun 1950.

\section{Kesimpulan}

Sejarah Bima pada masa kepemimpinan Sultan Salahuddin sebagai Sultan Bima memiliki banyak laporan politik dan surat-surat resmi terkait dengan adminstrasi politik kesultanan Bima yang tersimpan di museum samparaja, kesultanan Bima dalam perang kemerdekaan memilki keterlibatan langsung dalam gerakan nasional, keberadaan partai politik dan tumbuhnya organisasi-organisasi Islam yang baik di tanah ini menjadi salah satu bukti bagaimana Sultan Bima bersama para pegawai pemerintahan kerajaan juga masyarakat Bima secara umum memiliki sifat terbuka dan menerima perubahan politik kearah kemerdekaan yang diperjuangkan. Setelah proklamasi kemerdekaan dikumandangkan perjuangan bangsa Indonesia keluar dari cengkaraman colonial tidak berhenti begitu saja, bahkan sampai dengan akhir tahun 1950 perjuangan itu terus dilakukan untuk mendapatkan pengakuan kemerdekaan. Kesultanan Bima menjadi salah satu pionir dalam memperjuangan kemerdekaan diwilayah Indonesia Timur khususnya mewakili pulau Sumbawa yang memiliki tiga kerajaan yang masih berkuasa.

\section{Daftar Pustaka}

Abiddin, A. (2005). Pendudukan Jepang di Kecamatan Sape Kabupaten Bima Tahun 19421946,. Universitas Hasanuddin.

ANRI. (1929). Gouvernement Besluit (GB BT) No. Arsip 56. Di terangkan dalam BESLUIT tertanggal 20 Mei 1929.

Ismail, M. H. (2004a). Peran kesultanan Bima dalam Perjalanan Sejarah Nusantara. Lengge.

Ismail, M. H. (2004b). Peran Kesultanan Bima dalam Perjalanan Sejarah Nusantara. Lengge bekerjasama dengan Yayasan Adikarya IKAPI dan the Ford Foundation.

Ismail, M. H. (2008). Kebangkitan Islam di Dana Mbojo (Bima): 1540-1950. Penerbit Binasti.

Tajib, A. B. . (1995). Sejarah Bima Dana Mbojo. PT. HarapanMasa PGR. 